Mr. T. M. Greenhow moved the adoption of a petition to the House of Commons, of which the following is the substance :-

"That, in the opinion of your petitioners, the Bill for the better government of the medical profession, now before Parliament, is based on principles which are calculated to confer important benefits on the community.

"Your petitioners, therefore, humbly beg that those principles may receive the sanction of yonr honourable House."

Mr. Gregory seconded the motion, and it was at once agreed to.

Mr. Carter brought forward a petition in favour of certain clauses proposed to be introduced into the Poor-law Amendment Bill, to abolish the "tender system" in the appointment of medical officers in unions, and for other improvements in the medical relief of the poor.

Mr. Tor Bock having seconded the motion, it was adopted.

\section{OPINIONS OF ANTI-REFORMERS ON MEDICAL REFORM.}

\section{To the Editor of The Lancet.}

SIR :-Your giving insertion to the encloser in your valuable Journal, will oblige your most obedient servant,

George Atrinson,

Secretary to the Court of Examiners. Apothecaries' Hall, Dublin,

April 8, 1841.

\section{APOTHECARIES' HALL OF IRELAND.}

MEDICAL REFORM.

The governor and company of the Apo. thecaries' Hall of Ireland, coinciding in the opinion generally entertained that a change is required in the constitution of the medical profession in these kingdoms, have taken the subject into their consideration, in the hope of contributing to the removal of some of the difficulties with which it is surronnded, and of laying the foundation of an effectual and salutary reform.

The governor and company have been, for a long time, desirous of a general amendment of the laws which regulate medical affairs; but, in consequence of the divisions which have hitherto prevailed among the different presiding bodies, they despaired of effecting any arrangement which would have been commensurate with the wants of the profession as a whole, and had to restrict their attention to such changes as appeared to be called for in their own de. partment. Their views on this subject are embodied in the draft of a Bill, which they are prepared to submit to the $\mathrm{wisdom}$ of the Legislature, and, with regard to the nature of which, all that is necessary here to be stated is, that it is in conformity with the principles which they now wish to promulgate as the basis of a more general measure, the period having at length arrived when, through the concurrence of the different medical corporations, a full and comprehensive reform may be expected.

The governor and company, in delivering their opinions on so important a subject, wish to premise, that while they give a ready assent to the faulty constitution of the existing corporations, they entirely disbelieve they have operated injuriously upon the public, or that they are incapable of adaptation to the wants of the profession; they must express their regret, therefore, that any Bill should have been introdaced into Parliament having for its object the supersedence or annihilation of these institutions, which, with all their alleged imperfections, have sedulously administered to the wants of the people, and provided welleducated practitioners in every department of the healing art; and it cannot be too much urged that the grievances complained of have reference principally to the wellbeing of the profession itself, and that the public are only interested in the changes sought, so far as they are calculated to engender a better spirit of co-operation and harmony in the medical community.

The governor and company, however, representing a numerical majority of the practitioners in Ireland, are not the less sensible of the magnitude of the interests at stake, or less disposed to aid in a consummation so greatly to be desired; but while professing to have the same objects in view, they must dissent from a large portion of their brethren who would seek for them in the establishment of a "one faculty of medicine," in place of the tripartite representation which has so long existed, convinced by long experience that excellence in the respective de. partments can only be attained by sectional separation, and that the appointment of different institutions to preside over the branches of "pbysic," " surgery," and " pharmacy," is founded in wisdom, and advantageous to the public.

The governor and company consider that the real grievances under which the profession labours, arise, in the first place, from the irresponsible constitution and unequal privileges of the corporate bodies; and in the second, from the want of uniformity of education and reciprocity of rights among the members of the respective departments in the three kingdoms.

The governor and company accordingly propose the following legislative changes :-

1. A full extension of corporate rights and advantages to the licentiates belonging to each branch of the profession.

2. The establishment of uniform curricula of study for England, Ireland, and Scotland. 
3. The institution of a "general board of superintendence and control" in each kingdom-to be composed of an equal number of representatives from each branch of the profession, and to be elected annually by voting papers, (as proposed by Mr. Warburton,) whose duty it should be to regulate education - to appoint censors to attend on the different boards of examination-to grant licences for practice to (but not examine) those presenting diplomas from the different corporations-to recognise teachers and schools-to keep and publish registries of the qualified, and to act in general as a court of appeal and board of health.

4. "Diplomas in medicine" to be granted only by universities and colleges of physieians, " diplomas in surgery" by colleges of surgeons, and "diplomas in pharmacy" by the apothecaries' balls.

5. A licence for "general practice" to be granted in future only to candidates presenting the joint diplomas of the College of Surgeons and Apothecaries' Hall.

6. A right to recover professional charges to be conferred on those holding the licence of the board, and not upon others.

7. Individuals holding the licence of the board to be alone eligible to fill situations in the army and navy, and public institutions.

8. The establishment of an Apothecaries' Hall in Ediuburgh.

9. The rights and privileges of existing practitioners to be saved in the most full and ample manner.

By order,

George Atkinson, Secretary.

Mary-street, Dublin,

March 5, 1811.

\section{CHEMISTS AND DRUGGISTS.}

\section{To the Editor of THE LANCET.}

SIR:-It is to be deeply lamented that any partial influence should induce $\mathrm{Mr}$. Hawes to withdraw from his Medical Re. form Bill the proposed salutary and long wanted control over chemists and druggists. There does not appear to be any valid objection to their prescribing; but the condition should be, that no person commencing business, after a certain date, should be allowed to do so, unless licensed to practise medicine by the senate appointed under the Act. The surgeon-druggist is recognised in London, and is gradually establishing himself in provincial towns; therefore the union of the two branches should not be considered a test of disqua. lification. If Mr. Hawes persists in withdrawing his probibitive clauses for the regalation of chemists and druggists, it appears to me, as an inevitable consequence, that any attempt at medical reform will be inopera- tive, as every incompetent person will practise medicine by designatiog himself a chemist and druggist, alike injurious to the public and qualified practitioner. I an of opinion that the vested rights of the present chemists and druggists should be continued; which, granted, would remove all reasonable objection to the measure. They have no right to perpetuate a custom which the Bill wisely provides to remedy. There is a difficulty which presents itself, but that is not insurmountable, in regulating the sale of drugs. In all large towns it would not be so, as no person ought (under a penalty) to call himself a chemist and druggist (saving those now in trade), who has not been duly examined and licensed. In small towns and villages, not containing more than (say) two thousand inhabitants, the term druggist should only be used (pro. viding the party is not licensed). In small communities a small selection of drugs is only kept; and, under such circumstances, it would be needless to require a qualifi. cation. The advantage of licensing che. mists and druggists would be incalculable, inasmuch as it wonld secure a class of educated men whose knowledge of chemistry would enable them to detect those sophis. tications which are sold for want of the re. quisite skill in analysis. If Messrs. Hawes and Warburton would move for a committee of the House of Commons to inquire into the state of education of chemists and druggists, I fear the disclosure would be a national disgrace. How few among the community would be found to be acquainted with the rudiments of chemistry; much less to be competent to the important duty of toxicological investigation in aid of judicial inquiry.

At the present time large quantities of dried washing soda (in powder) is sold for the sesqui-carbonate, to the injury of the patient and of the reputable chemist. In trath, a catalogue of deteriorations might be named, which would convince the Legislature of the imperative necessity of pro. tecting the public against the nefarious practices of unprincipled men. None would more rejoice than the educated chemist, whose station in society would be properly appreciated, and his acquirements become a source of advantage and selfgratulation.

Any Bill would be incomplete that did not give the senate a power to appoint inspectors to examine into the qualities of drugs and chemicals. I hope that yourself and others will move in committee the infroduction of clauses relating to chemists and druggists; which, to any person acquainted with the subject, is an object not to be rejected.

INDICATOR.

Leicester, March 9, 1841. 